\title{
FENOMENA MITOS PENGHALANG PERKAWINAN DALAM MASYARAKAT ADAT TRENGGALEK
}

\author{
Ririn Mas'udah \\ Fakultas Syari'ah UIN Maliki Malang \\ Telepon: 085732830138
}

\begin{abstract}
Abstrak
Dalam hukum Islam, terdapat beberapa hal yang menyebabkan pernikahan tidak boleh dilaksanakan seperti saudara kandung dan pernikahan beda agama. Selain hukum Islam di dalam sistem adatpun juga mengenal adanya pernikahan yang dilarang. Tulisan ini memaparkan hasil penelitian di Kecamatan Pogalan Kabupaten Trenggalek tentang mitos penghalang perkawinan mlumah murep terkait dengan adat. Penelitian dilakukan dengan menggunakan pendekatan kualitatif dengan menguji data primer dan sekunder. Hasil penelitian menunjukkan bahwa mitos mlumah murep ini telah mendapat kepastian hukum dalam Islam yaitu berupa keharaman.
\end{abstract}

There are various factors which cause a marriage cannot be practiced such as sibling factor and inter-religious marriage. Besides Islam, customary law also recognizes that kind of system (forbidding marriage marriage). This paper presents the result of research in Pogalan sub district, Trenggalek on marriage barrier mlumah murep myth in relation to custom (adat). This research is conducted by using qualitative approach in assessing primary and secondary data. The result of this research reveals that $m l u$ mah murep myth is unlawful based on Islamic law.

Kata kunci: perkawinan, mlumah murep, mitos.

Perkawinan merupakan lembaga yang sah dan telah terjustifikasi oleh nash-nash agama (baik al-Qur'an maupun al-Hadits). Tujuan diadakannya perkawinan adalah untuk menjaga kelestarian umat manunisia. Dengan demikian, regenerasi umat manusia tetap terjaga dan berkesinambungan. Selain itu, perkawinan juga diciptakan sebagai sarana pemenuhan kebutuhan biologis yang sah, dan pelaksanaannya harus sesuai dengan tata cara dan ketentuan yang sudah digariskan oleh Islam.

Dalam sudut pandang yang lain, perkawinan diartikan sebagai suatu perjanjian yang suci kuat dan kokoh (mitsaqan ghalidzan), untuk hidup bersama secara sah antara seorang laki-laki dan seorang perempuan membentuk keluarga yang kekal, santun menyantuni, kasih mengasihi, tentram dan bahagia.[1]

Islam menetapkan dan memandang pentingnya perkawinan, sehingga suatu perkawinan hendaknya harus memalui dan mempertimbangkan dasar agama, moral dan sosial yang berlaku. Perkawinan dalam Islam dipandang sebagai sebuah ikatan yang kuat dan komitmen yang mutlak terhadap ke-

[1]Idris Ramulyo, Hukum Perkawinan Islam (Jakarta: Bumi Aksara, 1996), 1-2. 
hidupan, sosial dan untuk menjadi manusia terhormat.[2]

Pernikahan bagi manusia yang berbudaya, tidak cuma sekedar meneruskan naluri para leluhurnya secara turun temurun untuk membentuk suatu keluarga yang dalam suatu ikatan resmi antara laki-laki dan perempuan. Karena perkawinan adalah guna mengemban misi luhur untuk menciptakan keluarga yang bahagia dan sejahtera, yang saling memberi dan menerima, serta saling pengertian berdasarkan cinta kasih dalam rangka untuk "mengayu-hayuning bawana" menciptakan ketentraman dunia yang kekal dan abadi. [3]

Pernikahan menurut masyarakat jawa adalah hubungan cinta kasih yang tulus antara seorang pemuda dan pemudi yang pada dasarnya terjadi karena sering ketemu antara kedua belah pihak, yakni perempuan dan laki-laki. Satu pepatah jawa mengatakan "tresno jalaran soko kulino" yang artinya adalah cinta kasih itu tumbuh karena terbiasa.[4]

Perkawinan ideal menurut masyarakat jawa ialah suatu bentuk perkawinan yang terjadi dan dikehendaki oleh masyarakat. Suatu bentuk perkawinan yang terjadi berdasarkan suatu pertimbangan tertentu, tidak menyimpang dari ketentuan aturan-aturan, atau norma-norma yang berlaku di dalam masyarakat setempat.

Larangan menikah dalam masyarakat jawa dapat juga disebut dengan pembatasan jodoh. Peraturan-peraturan yang melarang perkawinan di antara seseorang dengan orang yang tertentu, pada umumnya adat pembatasan jodoh itu antara lain, bila jodoh atau calon jodoh itu berasal dari anggota yang dianggap terdekat, misalnya dari saudara-saudara misan. Orang jawa menyebutnya dengan istilah sedulur misan (tunggal mbah buyut). Yaitu angkatan 4 ke bawah. Bila calon

[2]Sayyid Sabiq, Fiqhus Sunnah, (Beirut: Darul Fikr, 1983), 5.

[3]Anjdar Any, Perkawinan Adat Jawa Lengkap, (Surakarta: P.T Pabean, 1985), 11.

[4]Suryo Negoro, Upacara Tradisional dan Ritual Jawa, (Surakarta: C.V Buana Raya, 2001), 16. jodoh berasal dari kelompok saudara ipar, orang jawa menyebutnya istilah krambil sejenjang. Menurut anggapan, pantangan itu bila dilanggar akan mengakibatkan salah satu di antara mereka meninggal. Bila calon jodoh itu tidak sesuai dengan hari kelahirannya, orang jawa menyebutnya dengan istilah Neptune ora cocok. Maka perjodohan di antara mereka dapat digagalkan, karena memungkinkan hidup suami istri itu tidak bahagia. Bila calon itu (anak gadis) anak saudara laki-laki ayah. Orang jawa menyebutnya dengan istilah sedulur pancer wali atau pancer lanang.[5]

Pertimbangan lain sebelum melangsungkan pernikahan adalah keturunan dan watak. Pertimbangan ini juga diperhitungkan karena terkait dengan konsep bibit, bobot dan bebet dalam membina hubungan suami istri.[6]

Bibit, mengandung pengertian derajat sosial orang tua anak perempuan. Apakah keturunan bangsawan, pejabat tinggi pemerintah, atau hanya anak rakyat biasa yang tidak punya status sosial apapun. Bibit juga menyelidiki kesehatan anak perempuan, apakah mempunyai sakit yang tidak bisa disembuhkan.

Bobot, dimaksudkan sebagai tingkat pendidikan anak perempuan, dan strata ekonomi orang tuanya. Strata ekonomi juga jadi bahan pemikiran agar jika kelak sudah berumah tangga, tidak selalu membebani orang tua saja. Menurut adat jawa, laki -laki adalah pemimpin dalam keluarga, oleh karena itu pihak laki-laki harus benar-benar sanggup, dan bukti kesanggupan itu salah satunya diperlihatkan dengan kecukupan materi/harta.

Bebet, suatu pertimbangan yang menilai bagaimana kualitas budi pekerti, moral kesetiaanya dikemudian hari. Pertimbangan ini juga menyangkut kualitas moral orang tuanya. Di kalangan orang jawa sangat dipahami pepatah kacang mangsa tinggal lanjaran yakni buah jatuh tidak jauh dari pohonnya.[7]

Di dalam sistem adat juga mengenal adanya

[5]Suryo Negoro, Upacara, 155.

[6]Suwardi Endraswara, Falsafah Hidup Jawa, (Cakrawala: Tangerang, 2003), 114.

[7]Sutrisno Sastro Utomo, Upacara Daur Hidup Adat Jawa, (Semarang: EFFHAR, 2005), 39-40. 
larangan dalam pernikahan. Namun, aturan yang ada lebih spesifik dan melampaui apa yang diatur oleh agama dan perundang-undangan. Seperti dalam adat masyarakat jawa, seseorang yang akan melangsungkan hajat pernikahan, ada pertimbangan-pertimbangan khusus dalam pemilihan jodoh atau disebut juga dengan pembatasan jodoh, yang di dalam istilah jawa dikenal dengan sebutan pasatowan.

Pesatowan adalah mempersatukan dua unsur dari pihak laki-laki dan perempuan. Di antara langkah-langkah yang dilakukan dalam pesatowan ini adalah: pertama, menghitung jumlah neptu (hari kelahiran) calon pengantin wanita ditambah jumlah hari kelahiran calon pengantin pria dibagi 5. Kedua, menggunakan perhitungan hari kelahiran pria dan wanita dan aksara Jawa. Pertimbangan lain adalah keturunan dan watak. Pertimbangan ini juga diperhitungkan karena terkait dengan konsep bobot, bebet, dan bibit dalam membina hubungan suami isteri.[8] Dan apabila pertimbangan-pertimbangan tersebut ada ketidakcocokan maka perjodohan mereka dapat digagalkan.

Sebagai masyarakat yang masih kental dengan tradisi adat, masyarakat Jawa masih percaya dengan adanya mitos-mitos. Karena sebagian besar orang jawa masih mengikuti paham kejawen, mitos yang berkembang di jawa juga sangat erat kaitannya dengan keyakinan atau kepercayaan.

Sebagaimana yang dipahami bersama, bahwa yang dinamakan dengan mitos adalah cerita suci berbentuk simbolik yang mengisahkan serangkaian peristiwa nyata dan immajiner yang menyangkut asal usul dan perubahan alam raya dan dunia, dewa-dewi, kekuatan-kekuatan atas kodrati, manusia, pahlawan dan masyarakat. Sistem berpikir yang bernuansa mitos tersebut terbawa oleh hampir seluruh orang jawa, baik mereka yang tergolong belum maju maupun mereka yang tergolong sudah maju.[9]

[8]Endraswara, Falsafah ,112-114.

[9]Muhammad Damami, Makna Agama Dalam MasyarakatJawa, (Yogyakarta: LESFI, 2002), 19.
Sebagai salah satu contoh adalah dalam masyarakat Bendorejo Kecamatan Pogalan Kabupaten Trenggalek. Masyarakat Bendorejo masih percaya dengan adanya mitos-mitos. Pengaruh kebiasaan mereka di dalam mempercayai mitos tersebut, sampai kepada urusan pernikahan. Salah satu mitos yang mereka percayai adalah adanya pantangan di dalam pernikahan. Mitos ini biasa dikenal dengan istilah mlumah murep yaitu larangan pernikahan ketika calonnya mempunyai saudara yang sudah menikah dengan orang sedesanya.

Sampai titik ini, dapat dipahami bahwa orang jawa (terutama di kelurahan Bendorejo) merasa memiliki budaya spiritual yang sifatnya turun temurun (dari para leluhur), baik karena terpengaruh oleh kehidupan atau oleh hubungan dengan nenek moyang terdahulu. Perasaan memiliki tersebut diapresiasi dengan pelestarian dalam bentuk aktualisasi sistem adat yang ada.

Fenomena adanya mitos larangan pernikahan mlumah murep di Desa Bendorejo Kecamatan Pogalan Kabupaten Trenggalek, menarik perhatian peneliti untuk mengakajinya secara lebih mendalam.

\section{METODE}

Jenis penelitian yang digunakan dalam studi ini adalah penelitian sosiologis atau empiris karena dalam hal ini peneliti mengamati secara langsung apa yang terjadi dalam masyarakat[10]. Selain itu, peneliti mengambil jenis penelitian ini karena sangat sesuai dengan judul yang diangkat yang bertujuan mengamati fenomena disuatu masyarakat.

Terkait dengan jenis pendekatan penelitian, dalam kesempatan ini penulis menggunakan pendekatan kualitatif yaitu suatu pendekatan penelitian yang menghasilkan data deskriptif berupa kata-kata tertulis atau lisan dari para informan dan perilaku yang diamati yang tidak dituangkan ke dalam variable atau hipotesis.

Berdasarkan pemaparan data maka

[10]Amiruddin dan Zainal Asikin, Pengantar Metode Penelitian Hukum (Jakarta: PT. Raja Grafindo Persada, 2004), 133. 
penelitian ini tergolong penelitian deskriptif yaitu penelitian yang berorientasi untuk menggambarkan secara sistematik dan akurat fakta serta karakteristik mengenai populasi atau menangani bidang tertentu. Data yang diperoleh tidak bermaksud mencari penjelasan, menguji hipotesis, membuat prediksi, maupun mempelajari implikasi. Jadi penelitian ini berusaha menggambarkan situasi atau fenomena yang diteliti.

Untuk mendapatkan data-data yang otentik dan akurat, penulis mengadakan pengamatan serta wawancara secara langsung terhadap objek yang diteliti, termasuk di dalamnya kejadian atau peristiwa-peristiwa tertentu yang erat hubungannya dengan penelitian. Dalam hal ini peneliti melakukan observasi dan wawancara dengan mengikuti kegiatan-kegiatan yang ada didesa Bendorejo untuk mengetahui mitos-mitos penghalang pernikahan. Metode pengolahan data yang digunakan dalam penelitian ini adalah: Editing, Classifying, Verifying, Analyzing, Concluding.

\section{HASIL DAN PEMBAHASAN}

\section{Hasil}

Mitos mlumah murep sulit untuk dilacak sumber sejarahnya. Kapan, di mana dan oleh siapa mitos ini mulai diperkenalkan. Berdasarkan hasil wawancara dengan para responden di lapangan, jawaban mereka sama ketika menjawab pertanyaan peneliti seputar sejarah mitos ini. Mereka menyatakan ketidaktahuan akan asal -asul dari mitos mlumah murep ini. Mereka hanya menyatakan bahwa mitos tersebut telah ada secara turun temurun dan melaksanakannya tanpa mengetahui asal-asulnya secara jelas.

Beberapa jawaban yang diberikan dari para responden, memperlihatkan bahwa mitos mlumah murep ini adalah benar-benar mitos yang dijadikan sebuah kepercayaan setempat. Artinya, mitos adalah kepercayaan turun temurun yang tidak begitu memperhatikan sejarah yang otentik.

Namun yang menarik adalah, bukanlah sebuah mitos jika tidak ada sebuah "hukuman" bagi pelanggarnya. Menurut peneliti, inilah yang kemudian menjadi pegangan masyarakat setempat, sekaligus alasan mengapa mereka mempercayai mitos itu. Artinya, mereka masih ada alasan bahwa mitos itu harus dipercaya. Dan alasan tersebut adalah bala' yang akan menimpa bagi yang melanggar mitos.

Yang disebut dengan mlumah murep adalah larangan perkawinan ketika calonnya mempunyai saudara yang sudah menikah dengan orang sedesanya. Yaitu misalnya, pihak putri berasal dari desa Bendo, sedangkan yang putra berasal dari Desa Dung Lurah. Sementara pihak putri memiliki sudara yang sudah menikah dengan salah seorang di Desa Dung Lurah, itulah yang disebut dengan mlumah murep, dan itu tidak boleh dilakukan.

Definisi tersebut, dengan jelas mengatakan bahwa ada jenis pernikahan yang menurut masayarakat Bendorejo, termasuk ke dalam pernikahan yang dilarang oleh adat. Maka, konsekuensi dari adat setempat adalah adanya sikap patuh dan taat atas ketentuan adat. Jika ketentuan tersebut dilarang, maka akan ada kekuatan supranatural yang akan menghukum mereka yang melanggar.

Contoh dari legitimasi ini adalah adanya pesan budaya yang coba dikembangkan di dalam masyaraat adat dalam semua inci kehidupan, lebihlebih dalam masalah pernikahan. Pesan budaya berupa toto dan titi. Yang dinamakan toto itu adalah tata cara kehidupan nenek moyang, sementara titi itu adalah tuntutan agar mengikuti tata cara tersebut

Falsafah toto titi yang diajarkan oleh tokoh adat setempat, merupakan suatu pola pengukuhan sistem kehidupan adat yang sudah disepakati dan digunakan secara turun temurun oleh nenek moyang dahulu kala. Menjalankan rutinitas adat, berarti menghargai para leluhur. Sementara tidak mau menjalankan adat-istiadat berarti tidak menghormati para leluhur. Maka, barang siapa yang tidak mau menghormati adat-istiadat leluhur, akan mendapat semacam hukuman sosiologis dari para tokoh dan masyarakat stempat.

Dari sini kemudian terlihat, bagaimana sistem pewarisan sistem adat pernikahan yang terjadi di dalam masyarakat Jawa. Barangkali inilah yang menjadi pangkal menguatnya serta berkembangnya mitos mlumah murep sampai zaman modern ini. 
Sebagaimana yang telah disinggung di atas, bahwa salah satu faktor mengakarnya mitos adalah adanya sebuah hukuman atau bala' yang akan menimpa orang yang melanggarnya. Tidak terkecuali pada mitos mlumah murep ini.

Mitos mlumah murep ini dipercaya oleh mayoritas masyarakat setempat, karena memiliki kekuatan magis atau bala' (Supranatural). Menurut pengalaman masyarakat setempat, bala' bagi mereka yang melanggar ketentuan adat tersebut memang bermacam-macam bentuknya. Namun yang jelas, semua bala' tersebut diyakini akan datang atau menimpa pelaku perkawinan mlumah murep. Bahkan karena diyakini akan datangnya suatu bencana atau semacam musibah yang akan menimpa pelaku perkawinan mlumah murep, maka masyarakat setempat tidak banyak yang berani melakukannya. Adapun dampak langsung dialami oleh mereka yang melakukan perkawinan mlumah murep dapat berupa diserang sebuah penyakit, perceraian, kemandulan, bahkan sampai pada kematian.

Selain beberapa macam musibah yang menimpa mereka yang melakukan perkawinana mlumah murep tersebut di atas, ada juga musibah dalam bentuk lain, seperti ada keluarga yang tidak mendapatkan keturunan. Tidak hanya itu saja, akibat yang sangat tragis dari perkawinan ini yang diyakini oleh masyrakat Bendorejo sampai saat ini adalah berupa kematian.

Namun ada beberapa orang yang secara tertutup, tidak mengakui akibat atau bala' yang terjadi pada pelaku perkawinan itu. Misalnya seorang tokoh Agama setempat yang menyatakan bahwa kita tidak boleh meyakini kepercayaan tersebut. Pernyataan tersebut seolaholah menyatakan bahwa ada segolongan masyarakat yang mencoba melawan arus mainstream. Namun ketika dikonfirmasi, mengenai sejauh mana pemikiran ini dapat merubah cara pandang masyarakat tentang mitos mlumah murep pada umumnya, mereka menyatakan bahwa hal tersebut hanya keyakinan pribadi, namun mereka secara pribadi tidak begitu berani menyatakan kepada masyakat, karena sebagian besar masyarakat daerah tersebut sudah terlanjur meyakininya.

Berbeda dengan "golongan tua", kaum muda-mudi desa Bendorejo (terutama yang sudah mengenyam pendidikan di Perguruan Tinggi), tidak begitu meyakini dan percaya atas mitos mlumah murep tersebut. Pasalnya, zaman ini adalah zaman modern, maka segala sesuatunya harus dapat dinalar dengan otak. Peristiwa-peristiwa yang terjadi atau yang dikayini seputar mlumah murep tersebut hanya mitos belaka. Namun lagi-lagi, golongan ini hanya dapat berwacana, mereka kewalahan ketika akan melaksanakan perkawinan.

\section{Pembahasan}

Pada dasarnya Islam datang dilengkapi dengan tuntunan hidup bagi pemeluknya. Tuntunan-tuntunan tersebut secara gambalng tercantum atau termuat di dalam al-Qur'an dan Sunnah Nabi saw. Sebagaimana dijelaskan dalam al-Qur'an sebagai berikut[11]

\$tBur ÏB 7p-/!\#y Î̂ ÇÚöF \{\$\# wur

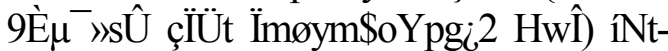
Bé\& Nä3ä9\$sVøBr\& 4 \$”B \$uZôÛ§sù lû É=»tGÅ3ø9\$\# “̈̈B \&äóÓx« $4 \not$ OèO $4 n<\hat{I})$

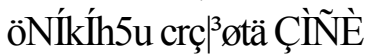

"Dan Tiadalah binatangbinatang yang ada di bumi dan burung-burung yang terbang dengan kedua sayapnya, melainkan umat (juga) seperti kamu. Tiadalah Kami alpakan sesuatu pun dalam al-Kitab, kemudian kepada Tuhan lah mereka dihimpunkan."

Ayat tersebut dengan gamblang menjelaskan bahwa Allah (melalui al-Qur'an), telah mengatur segala hal yang berurusan dengan manusia, lebihlebih urusan tersebut berkaitan dengan aqidah atau keyakinan. Oleh karena itu, perilaku apa saja (lebihlebih yang berkaitan langsung dengan aqidah), harus mendapat "izin atau restu" dari al-Qur'an dan Sunnah Nabi.

Di dalam al-Qur'an, Allah menceritakan bagaimana masyarakat kaum kafir Qurays melakukan hal yang sama. Masyarakat Qurays saat itu, gemar melakukan aktifitas warisan nenek moyang mere-

[11] QS. Al-An'am (6): 38. 
ka, seperti menghambakan diri mereka sendiri pada beberapa berhala atau berupa perilaku dan keyakinan atau kepercayaan-kepercayaan. Cerita ini dilestarikan di dalam al-Qur'an[12]:

\#sÎr) @ï\% ãNßgs9 (\#qãêI7@?\$\#!

\$tB tAtRr\& a!\$\# (\#qä9\$s\% ö@t/ Bî̂̂®RKtR !\$tB \$uZøxÿø9r\& Ïmøn=tã ! \$tRuä!\$t/\#uä 3 öqs9urr\& c\%x. öNèdät!\$t/ \#uä w cqè=É) $\div$ èt \$krøx@ wur tbrßtGôgt ÇÊĐÉÈ

"Dan apabila dikatakan kepada mereka: Ikutilah apa yang telah diturunkan Allah,"mereka menjawab: (Tidak), tetapi Kami hanya mengikuti apa yang telah Kami dapati dari (perbuatan) nenek moyang kami." "Apakah mereka akan mengikuti juga), walaupun nenek moyang mereka itu tidak mengetahui suatu apapun, dan tidak mendapat petunjuk?"

Atau di dalam ayat yang lain yang berbunyi:[13] \#ŝ̂)ur@ @ï\% óOçlm; (\#öqs9\$yès? $4 \mathrm{n}<\hat{\mathrm{I}})$ ! \$tB tAtRr\& a $\$$ \#\# n<î)ur ÉAqß\$9\# (\#qä9\$s\% \$uZç6óiym \$tB \$tRôy'ur Ïmøn=tã !\$tRuä!\$t/\#uä 4 öqs9urr\& tb\%x. öNèdät!\$t/\#uä w tbqßJn=ồt \$køx $@$ wur tbrßtGöku ÇÊÉÉlE

"Apabila dikatakan kepada mereka: Marilah mengikuti apa yang diturunkan Allah dan mengikuti Rasul."mereka menjawab: Cukuplah untuk Kami apa yang Kami dapati bapak-bapak Kami mengerjakannya." dan Apakah mereka itu akan mengikuti nenek moyang mereka walaupun nenek moyang mereka itu tidak mengetahui apa-apa dan tidak (pula) mendapat petunjuk?."

[12]QS. al-Baqarah (2): 170.

[13]QS. al-Maidah (5): 104.
Ayat yang terdapat dalam surat al-Baqarah dan al-Maidah di atas, merupakan gambaran dan kisah bahwa beberapa ratus tahun yang lalu ada sebuah kehidupan yang memiliki karakteristik yang sama dengan masyarakat yang tinggal di desa Bendorejo. Lalu bagaimana tanggapan Islam dengan masyarakat tersebut? Dengan jelas dan tegas alQur'an menolak cara hidup mereka yang hanya menggantungkan diri pada ajaran dan keyakinan nenek moyang yang tidak memiliki landasan hukum yang jelas. Artinya, ketika perilaku atau keyakinan hidup tidak memiliki landasan hukumnya, maka perilaku tersebut atau keyakinan tersebut harus dihindari atau ditolak pemberlakukannya.

Di dalam Islam, umat diajarkan bahwa tidak ada kekuatan dan daya melainkan kekuatan yang datang dari-Nya. Begitu pula dengan keyakinan yang terdapat didalam mlumah murep, mitos ini memastikan terjadinya kemudharatan yang pasti menimpa mereka yang melanggar ketentuanketentuan mitos.

Beberapa keterangan dari ayat-ayat di atas, secara makro menyalahkan segala perilaku yang mengarahkan seseorang untuk menggantungkan harapannya kepada selain Allah. Selain itu, melalui ayat-ayat tersebut, Islam mengajarkan dan menegaskan bahwa, ketentuan dan kejadian yang sudah dan belum terjadi merupakan rahasia Allah yang harus diyakini adanya. Dengan demikian, spekulasi -spekulasi manusia yang mencoba melawan ketentuan-ketentuan itu pantas untuk dihindari atau ditolak. Lebih-lebih ketika spekulasi itu tidak ada "cantolannya" di dalam al-Qur'an dan Hadits.

Pendekatan yang tidak kalah menariknya juga yaitu pendekatan dengan konsep al-Syatibi yaitu hikmatu al-tasyri nya, kita melihat kalau konsep mlumah murep ini tetap dipertahankan dengan segala konsekuensinya dan dengan segala keyakinan yang ditimbulkannya, maka perintah hifzu aldin yang juga merupakan misi utama syari'at akan terabaikan, bahkan dengan kata lain, aqidah umat akan dipertaruhkan.

Kalau kita yakini bahwa mlumah murep ini sebagai adat dan keyakinan lokal yang harus dipertahankan. Maka sangat jelas, mitos ini juga bertentangan dengan ajaran-ajaran jawa sendiri. Seperti ojo ndisei kerso. Artinya, bahwa kehidupan kita di 
muka bumi ini adalah sebuah rahasia Tuhan, yang mana kita tidak boleh mendahului ketentuan-ketentuan-Nya. Kemaslahatan yang coba ditampilkan oleh mlumah murep dengan adanya garansi berupa terjauhkannya bala' jika pasangan suami istri tidak melakukan perkawinan $\mathrm{mlu}$ mah murep tersebut. Hal ini baik, dan sudah dijelaskan panjang lebar dalam pembahasan di atas.

Namun konsep tersebut bukanlah tanpa kemudharatan, artinya ada sisi yang cukup krusial jika mitos tersebut tetap dipertahankan. Kemudharatan yang dimaksud adalah adanya pendangkalan keimanan atau akidah, akibat adanya over convidence yang dimiliki oleh mitos itu. Sikap yang mencoba memastikan dan mewajibkan akan datangnya sebuah musibah, baik berupa penyakit, sampai kepada kematian yang disebabkan oleh mitos tersebut, merupakan sikap over confidence, dan sangat jelas berlawanan dengan ajaran Jawa ojo ndisei kerso.

Ajaran ojo ndisei kerso merupakan sebuah kepasrahan, bahwa setiap manusia tidak memiliki kewenangan atau kekuatan untuk bisa memastikan apa yang akan terjadi pada diri mereka sendiri esok hari. Dengan demikian, Islam mengajarkan sikap tawakkal sebagai sebuah langkah memasrahkan diri atas ketentuanketentuan yang sudah digariskan Tuhan.

Beberapa dampak yang disebutkan di atas, yang diyakini sebagai akibat dari pelanggaran mitos mlumah murep, menurut peneliti (dalam perspektif ini) terlalu gegabah. Kematian, penyakit yang bertahun-tahun bahkan sampai pada kematian, pada dasarnya bisa menimpa siapa saja di dunia ini. Adapun mitos yang sudah melekat di dalam sanubari masyarakat Bendorejo tersebut, di suatu saat bahkan di setiap saat hanya akan melahirkan sebuah sugesti. Dengan sugesti itulah, menurut peneliti semua kejadian yang dialami oleh pelaku perkawinan mlumah murep dianggap sebagai bentuk balasan atau hukuman yang diterima oleh mereka.

Namun yang lebih mengkhawatirkan adalah, apabila masyarakat di desa Bendorejo, meyakini mitos mlumah murep, padahal mereka tahu kalau perbuatan tersebut tidak terdapat ketentuan hukum atau bahkan tidak menghiraukan ketentu- an al-Qur'an dan Sunnah, maka menurut Syaikh Abdullah di dalam Sullami al taufiq, sikap tersebut secara langsung telah bertentangan dengan aqidah Islam dan tidak patut untuk diikuti.[14]

\section{KESIMPULAN DAN SARAN}

\section{Kesimpulan}

Berdasarkan beberapa kajian yang telah dilakukan oleh peneliti, baik secara teoritis konsepsional maupun beberapa pendekatan-pendekatan analisis, yang digunkan untuk melihat fenomena mitos mlumah murep ini, maka akhirnya penelitian ini sampai pda beberapa kesimpulan. Pertama, bahwasannya masyarakat Desa Bendorejo, pada dasarnya tidak mengetahui asal usul dan sejarah dari mitos mlumah murep ini. Mereka hanya taqlid (mengikuti tanpa mengetahui dasar dan sumbernya) saja, serta hanya meyakini bahwa mitos ini adalah kepercayaan turun temurun dari leluhur mereka. Adapun yang dimaksud dengan mlumah murep adalah larangan perkawinan ketika calonnya mempunyai saudara yang sudah menikah dengan orang sedesanya.

Kedua, dampak yang diyakini oleh masyarakat desa Bendorejo terhadap mereka yang melakukan perkawinan mlumah murep sampai saat ini misalnya berupa keretakan di dalam berumah tangga, hingga perceraian, kemandulan (tidak bisa punya anak), dan penyakit menahun akan menimpa mereka yang melanggar ketentuan tersebut. Bahkan yang paling mengerikan adalah pelaku perkawinan mlumah murep dapat mengakibatkan kematian salah satu anggota keluarga mereka bahkan dapat menyebabkan salah seorang di antara mereka akan mengalami gangguan jiwa. Ketiga, mitos mlumah murep merupakan suatu kepercayaan atau keyakinan masyarakat desa Bendorejo yang tidak sesuai dengan aqidah Islam. Oleh karena itu, sebagai seorang mukmin dan muslim, tidak boleh meyakini dan menerapkan mitos tersebut.

[14]Syaikh Abdullah bin Husain ibnu Thohir bin Muhammad bin Hasyim, Sullami al Taufiq, (Semarang: Karya Thoha Putra, tt), 10. 


\section{Saran}

Bagi seorang muslim, sudah seharusnya meninggalkan atau menolak pelaksanaan mitos mlumah murep tersebut. Karena mitos tersebut dengan jelas dapat merusak aqidah umat. Selian itu, mitos-mitos tersebut tidak memiliki mashlahah yang signifikan di dalam pembentukan rumah tangga yang sakinah, mawaddah dan rahmah.

Setelah mengatahui bahaya atau kemudharatan yang ditimbulkan dari mitos tersebut, maka sikap

\section{DAFTAR RUJUKAN}

Abdullah, Syaikh, bin Husain ibnu Thohir bin Muhammad bin Hasyim. (tt). Sullami al Taufiq, Semarang: Karya Thoha Putra.

Amiruddin dan Zainal Asikin. 2004. Pengantar Metode Penelitian Hukum. Jakarta: PT. Raja Grafindo Persada.

Asmawi, Mohammad. 2004 Nikah Dalam Perbincangan dan Perbedaan. Yogyakarta: Darussalam.

Ayyub, Syaikh Hasan. 2004. Fiqh Keluarga. Jakarta: Pustaka Al-Kautsar.

Azmar, Saifuddin. 2001. Metode Penelitian. Yogyakarta: Pustaka Pelajar Offset.

Damami, Muhammad. 2002. Makna Agama Dalam Masyarakat Jawa. Yogyakarta: LESFI.

Endraswara, Suwardi. 2003. Falsafah Hidup Jawa. Tangerang: Cakrawala.

Hadikusuma, Hilman. 1990. Hukum Perkawinan Indonesia menurut: Perundang-undangan hukum Adat, hukum Agama. Cet. II; Jakarta: Mandar Maju.

Hakim, Rahmat. 2000. Hukum Perkawinan Islam. Bandung: CV Pustaka Setia.

Hariwijaya. M. 2005. Perkawinan Adat Jawa. Jogjakarta: Media Abadi.

J. Moleong, Lexy. 2002. Metodologi yang harus dikembangkan adalah pertama, melakukan da'wah dan pencerahan yang intens terhadap mereka yang masih meyakini dan mengamalkan mitos tersebut. Metode yang rahmatan lil 'alamin serta dengan hikmah dan mau'izah hasanah adalah metode yang harus dikembangkan didalam berdakwah kepada mereka, agar jangan sampai terjadi salah paham diantara umat. Kedua, upaya untuk menyelamatkan diri dan keluarga, serta umat pada umumnya yang belum terjerumus di dalam melakukan hal yang bathil tersebut.

Penelitian Kualitatif. Bandung: PT. Remaja Rosda Karya.

Negoro, Suryo. 2001. Upacara Tradisional dan Ritual Jawa. Surakarta: C.V Buana Raya.

Nuruddin, Amiur, dan A.A. Tarigan. 2004. Hukum Perdata Islam di indonesia; studi kritis perkembangan Hukum Islam dari fikih, UU No 1/1974 sampai KHI Jakarta: Kencana.

Nuruddin, Amiur, dan Azhari Akmal Tarigan. 2004. Hukum Perdata Islam Di Indonesia. Jakarta: Prenada Media.

Purwadi. 2005. Upacara Tradisional Jawa. Yogyakarta: Pustaka Pelajar. .2004. Tata Cara Pengantin Jawa. Yogyakarta: Media Abadi.

Rofiq, Ahmad. 2000. Hukum Islam di Indonesa. Jakarta: Raja Grafindo Persada.

S, Margono. 2000. Metode Penelitian Pendidikan. Cet. II; Jakarta: Rineka Cipta.

Sabiq, Sayyid. 1983. Fiqhus Sunnah. Beirut: Darul Fikr.

Sudjana, Nana dan Ahwal Kusumah. 2000. Proposal Penelitian di Perguruan Tinggi. Bandung: Sinar Baru.

Sunggono, Bambang. 2003. Metodologi Penelitian Hukum. Jakarta: PT. Raja Grafindo Persada.

Utomo, Sutrisno Sastro. 2005. Upacara Daur Hidup Adat Jawa. Semarang: EFFHAR. 